НАУКОВИЙ ВІСНИК

Scientific messenger of Lviv National University of
Veterinary Medicine and Biotechnologies

110

(y)

CEPIS: BETEPHHAPH HAYKK

Том 23 № 104

2021
Науковий вісник Дьвівського національного університету ветеринарної медицини та біотехнологій імені С.3. Гжицького. Серія: Ветеринарні науки

\author{
Scientific Messenger of Lviv National University
} of Veterinary Medicine and Biotechnologies. Series: Veterinary sciences

UDC 619.616-091:598.1:591(075.8)

\title{
Peculiarities of pathomorphological examination of snakes
}

\author{
M. P. Horvat, R. S. Dankovych, M. R. Dankovych \\ Stepan Gzhytskyi National University of Veterinary Medicine and Biotechnologies Lviv, Ukraine
}

Article info

Received 14.10.2021

Received in revised form 15.11.2021

Accepted 16.11.2021

Stepan Gzhytskyi National University of Veterinary Medicine and Biotechnologies Lviv, Pekarska Str., 50, Lviv, 79010, Ukraine. Tel.: +38-050-259-60-86 E-mail: dancor1802@i.ua
Horvat, M. P., Dankovych, R. S., \& Dankovych, M. R. (2021). Peculiarities of pathomorphological examination of snakes. Scientific Messenger of Lviv National University of Veterinary Medicine and Biotechnologies. Series: Veterinary sciences, 23(104), 110-118. doi: $10.32718 /$ nvlvet10418

The article presents data on the morphology of snakes and features of the pathomorphological study of representatives of this suborder of reptiles. There is also a brief description of the most common pathological conditions of reptiles, which are fatal without adequate veterinary care. Characteristic morphological features of snakes are described: a long narrow body, which is adapted for crawling, most of the internal organs are elongated, placed asymmetrically, some of them have lost their paired part. The skin of snakes is dry, almost devoid of glands, the outer layers of the epidermis form horny scales and shields. The snake's heart is three-chambered, three blood trunks independently depart from the ventricle separated by an incomplete septum: two aortic arches and the pulmonary artery, and the carotid arteries that supply arterial blood to the head and forelimbs depart only from the right aortic arch. Gas exchange occurs mainly in the lungs (in most snakes, the left lung is rudimentary) and the mechanism of respiration of the suction type. The digestive organs are elongated, and the liver is monocotyledonous. Metanephric kidneys provide isolation and water exchange. The body temperature of reptiles is not constant and largely depends on the ambient temperature (poikilotherm). Before the opening, the anamnesis is collected, and the type of reptile is determined. During the pathological examination, it is necessary to follow safety rules, especially when examining poisonous snakes. On external review, the skin is carefully inspected, attention is paid to the presence of ectoparasites (especially mites), remnants of the epidermis after the last molt, external damage, and so on. The mucous membrane of the oral cavity, teeth, external nostrils, cloacal slit are examined. To access the body cavity, a paramedial incision is made in the body cavity wall, bypassing large vessels. Internal organs should be discussed following the preservation of their anatomical and physiological relationships. In the process of pathomorphological examination, it is necessary to select material for histological, histochemical, bacteriological, virological, mycological, parasitological, and other types of laboratory tests to use a comprehensive approach diagnosis. Particular attention should be paid to diseases common to reptiles and humans (salmonellosis, leptospirosis).

Key words: reptiles, snakes, pathomorphological examination, dissection, morphology, pathoanatomy.

\section{Особливості патоморфологічного дослідження змій}

\author{
М. П. Горват, Р. С. Данкович, М. Р. Данкович
}

Львівський національний університет ветеринарної медицини та біотехнологій імені С. 3. Гәсииького, м. Львів, Україна

У статті наведені дані шодо морфології змій та особливостей патоморфологічного дослідження представників зазначеного підряду рептилій. Також представлено короткий опис найбільш частих патологічних станів рептилій, які (без надання адекватної ветеринарної допомоги) мають летальний вислід. Описані характерні морфологічні особливості змій: довге вузьке тіло, яке пристосоване для повзання, більшість внутрішніх органів видовжені, розміщені асиметрично, деякі з них втратили свою парну частину. Шкіра у змій суха, майже позбавлена залоз, зовнішні шари епідермісу утворюють рогові луски та шитки. Серие змій трикамерне, від розділеного неповною перегородкою шлуночка самостійно відходять три кровоносні стовбури: дві дуги аорти $і$ легенева артерія, а сонні артерії, щзо забезпечують артеріальною кров'ю голову та передні кіниівки відходять лише від правої дуги 
аорти, у судинах тулуба циркулює змімана кров. Газообмін відбувається, в основному, в легенях (у більшості змій ліва легеня рудиментарна), а механізм дихання присмоктувального типу. Органи травлення видовжені, печінка однодольна. Виділення і водний обмін забезпечують метанефричні (тазові) нирки. Температура тіла рептилій непостійна $і$ в значній мірі залежить від температури навколишнього середовища (пойкілотермія). Перед початком розтину збирають анамнез та визначають вид рептиліі. Під час патологоанатомічного дослідження необхідно дотримуватись правил техніки безпеки, особливо за дослідження отруйних змій. За зовнішнього огляду ретельно досліджують шкіру, звертають увагу на наявність ектопаразитів (особливо клішів), залишки епідермісу після останньої линьки, зовнішні пошкодження тошо. Детально досліджують слизову оболонку ротової порожнини, зуби, зовнішні ніздрі, клоакальну щілину. Для доступу до порожнини тіла проводять парамедіальний розріз стінки порожнини тіла, оминаючи великі судини. Внутрішні органи слід досліджувати дотримуючись принципу збереження їх анатомічних та фізіологічних взаємозв'язків. У процесі патоморфологічного дослідження необхідно відбирати матеріал для гістологічного, гістохімічного, бактеріологічного, вірусологічного, мікологічного, паразитологічного та інших видів лабораторних досліджень, користуватись комплексним підходом за встановлення діагнозу. Особливу увагу слід звертати на хвороби, які спільні для рептилій та людей (сальмонельоз, лептоспіроз).

Ключові слова: рептилї, змї, патоморфологічне дослідження, розтин, морфологія, патанатомія.

\section{Ветуп}

Плазуни (рептилії) - це вищі хребетні пойкілотермні (холоднокровні) тварини, які пристосовані до наземного способу життя та широко поширені у природних умовах. Сучасних плазунів поділяють на чотири ряди, що об'єднують понад 7500 сучасних видів, які заселили майже усі кліматичні регіони земної кулі за винятком приполярних та полярних областей (за Північне полярне коло поширюються ареали лише двох видів - гадюки звичайної та ящірки живородної), що спричинило велику різноманітність життєвих форм. Плазунів утримують в зоопарках та зоокуточках, серпентаріях, океанаріумах, домашніх тераріумах, спеціально організованих фермах для вирощування рептилій, в наукових та науково-дослідних установах, як експериментальних тварин та продуцентів отрути тощо (Coborn, 1991; Kotsiumbas et al., 2011; Chuliuk, 2021).

Характерні ознаки плазунів: суха шкіра, що майже позбавлена залоз, зовнішні шари епідермісу утворюють рогові луски та щитки, трикамерне серце (за винятком крокодилів, у яких серце чотирикамерне), від розділеного неповною перегородкою шлуночка самостійно відходять три кровоносні стовбури: дві дуги аорти і легенева артерія, a сонні артерії, що забезпечують артеріальною кров'ю голову та передні кінцівки відходять лише від правої дуги аорти, у судинах тулуба циркулюе змішана кров. Газообмін відбувається, в основному, в легенях, а механізм дихання присмоктувального типу. Виділення і водний обмін забезпечують метанефричні (тазові) нирки. Збільшені відносні розміри головного мозку особливо за рахунок збільшення півкуль і мозочка. Температура тіла рептилій непостійна і в значній мірі залежить від температури навколишнього середовища (пойкілотермія). Загальний рівень метаболізму вищий, ніж у земноводних, але нижчий ніж у птахів та ссавців. Запліднення внутрішне, личинкова стадія відсутня, ембріональний розвиток (у більшості видів) відбувається в повітряному середовищі з утворенням зародкових оболонок - амніона, серози і алантоїса. Переважна більшість видів рептилій є яйцекладними тваринами, також реєструється яйцеживородіння та справжнє живородіння. У багатьох видів плазунів зустрічається партеногенез (Kotsiumbas et al., 2011; Girling, 2013; Zakharenko et al., 2015).

Змії відносяться до класу Рептилій, ряду Лускатих і підряду Зміїних. На сьогодні у світі налічується понад 3600 видів змій (Coborn, 1991; Melidone \& Gibson, 2010; Kotsiumbas et al., 2011; Funk \& Bogan, 2019).

В наш час зростає попит на спеціалістів ветеринарної медицини, які володіють знаннями нормальної та патологічної морфології рептилій. Вітчизняна література на дану тему $є$ досить лімітованою. Змії володіють морфологічними особливостями, що вимагає особливого підходу та техніки розтину.

Метою даного дослідження є вивчення морфології змій та методики їх патоморфологічного дослідження, а також короткий огляд найбільш частих захворювань представників зазначеного підряду рептилій.

\section{Матеріал і методи досліджень}

Дослідження змій проводили на кафедрі нормальної та патологічної морфології і судової ветеринарії Львівського національного університету ветеринарної медицини та біотехнологій імені C. 3. Гжицького. Досліди провели на декількох видах змій: тигрових пітонах $(\mathrm{n}=7)$, молочних зміях $(\mathrm{n}=8)$, полозах тонкохвостих $(\mathrm{n}=6)$, гадюках звичайних $(\mathrm{n}=5)$, які загинули перебуваючи в приватних колекціях, зоокуточках або природніх умовах на території Львівської, Тернопільської та ІваноФранківської областей. Розтин змій проводили 3 діагностичною метою за методом Шора. Під час розтину проводили препарування внутрішніх органів, також відбирали матеріал для гістологічного дослідження.

\section{Результати та їх обговорення}

Змії мають довге вузьке тіло, пристосоване для повзання, більшість внутрішніх органів видовжені, розміщені асиметрично, деякі з них втратили парну частину. Тіло змії можна розділити на чотири квадранти:

I. Основні структури першого квадранта включають голову, стравохід, серце і трахею.

II. Передня васкуляризована частина легені 
(легень), а також печінка і шлунок знаходяться в другому квадранті.

III. Третій квадрант містить жовчний міхур, селезінку, підшлункову залозу (або спленопанкреас) i статеві залози. Між цими структурами проходить тонка кишка і прилегла до них каудальна частина правої легені.

IV. Четвертий квадрант містить ділянку між тонкою і товстою кишками, сліпою кишкою (у удавів і пітонів), а також включає нирки, органи статевої системи, клоаку, хвіст.

Техніка розтину змій. Перед початком розтину збирають анамнез, а надалі проводять ретельний зовнішній огляд трупа змії. Оцінюють іiї вигляд та ідентифікують вид (рис. 1, 2). Детально досліджують шкіру. Зовнішній епідермальний шар у змій формує рогові лусочки, які покривають всю поверхню тіла змії. В удавів та пітонів оглядають бічні шпори, які розташовані з обох сторін клоаки. Шпори є зовнішнім компонентом залишків тазових кінцівок в удавів та пітонів. Вони представлені короткими, гострими, вкритими кератином шпороподібними структурами. Добре розвинена мускулатура дозволяе шпорам рухатися, що важливо для самців під час залицяння та копуляції. Самці мають більші шпори, ніж самки. У деяких змій епідермальна луска формує специфічні структури, наприклад “брязкальце” на хвості у Північно Американських гримучих змій (Rutland et al., 2019),

Ретельно оглядають поверхню шкіри, звертають увагу на наявність ектопаразитів (особливо кліщів) та залишки шкіри після останньої линьки. Детально оглядають очі, які на початку линьки мутніють. Відшарування верхніх шарів шкіри під час линьки починається з переднього кінця морди, а потім шкіра панчохою сповзає з тіла. У хворих і виснажених змій линька відбувається частіше і шкіра відділяється шматками (Kotsiumbas et al., 2011; Funk \& Bogan, 2019).

Досить поширеним захворюванням шкіри змій є гнійний дерматит, що виникає при потраплянні у шкіру Pseudomonas spiralis та Aeromonas spiralis. При цьому в шкірі утворюються абсцеси заповнені крихтоподібним гноєм та оточені фіброзною капсулою. Інколи на дорзальній стороні тіла у шкірі виявляють дрібні міхурці, що припіднімають лусочки (везикулярна хвороба). Вони виникають через надмірну вологість в тераріумі. Утворення вузликів у шкірі окрім бактерій і грибків також можуть спричинити паразити. Зокрема в шкірних вузликах іноді виявляють фіни стрічкових червів, мікрофілярії, личинки нематод. На шкірі змій можуть локалізуватись опіки, пошкодження, що спричинені кормовими тваринами.

Під час зовнішнього огляду також досліджують слизову оболонку ротової порожнини, зуби, зовнішні ніздрі, клоакальну щілину.

Після цього перевертають змію в дорсальне положення так, щоб черевна сторона була розташована догори для вільного доступу до органів під час власне розтину.

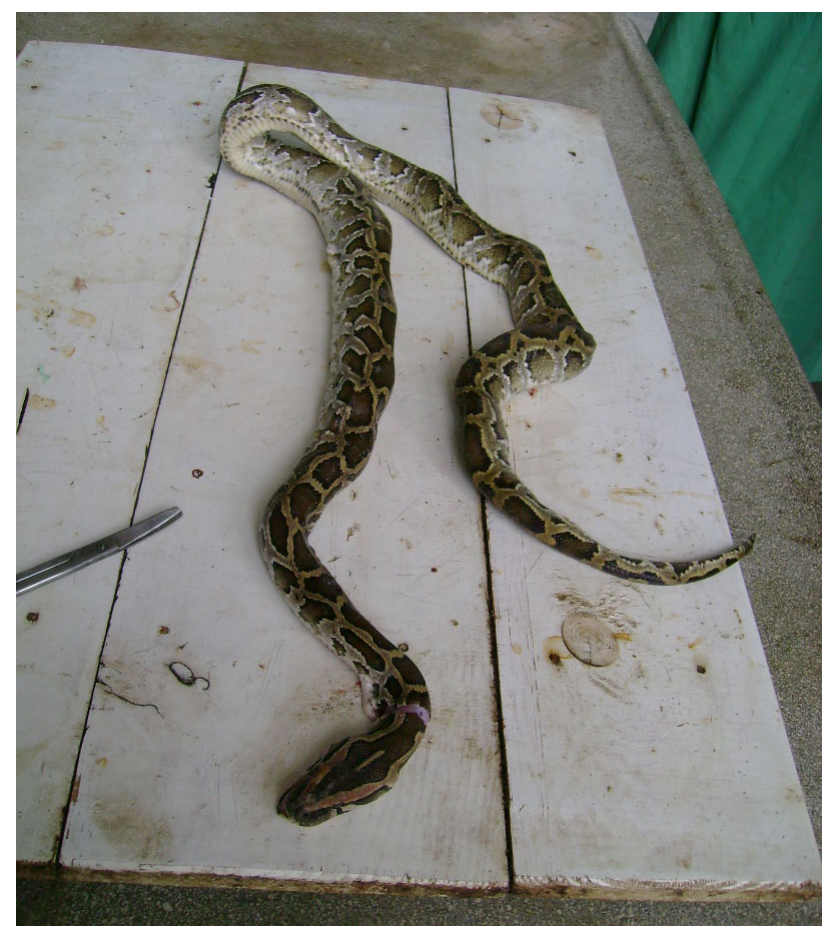

Рис. 1. Розтин тигрового пітона

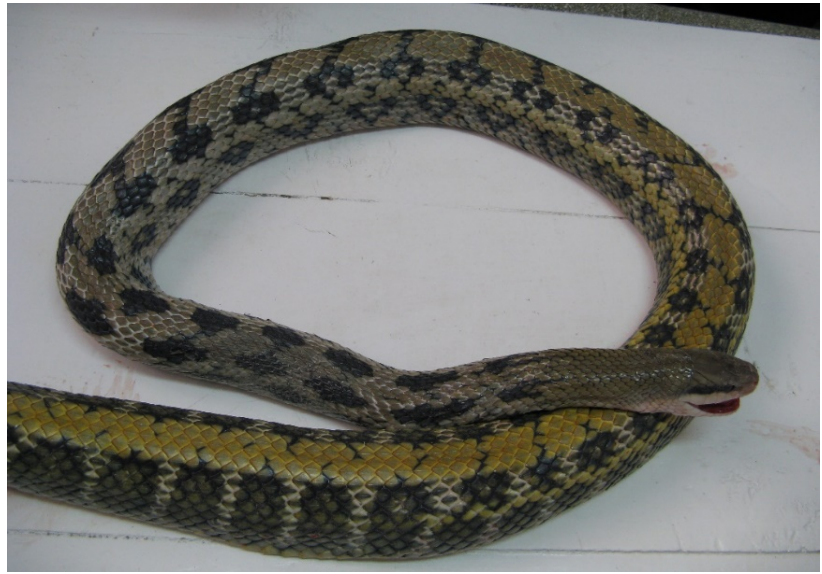

Рис. 2. Розтин тонкохвостого полоза

Відпрепаровують та знімають шкіру. Використовуючи ножиці, бажано тупокінцеві, роблять невеликий надріз через шкіру з черевної сторони безпосередньо перед клоакою. Краще спочатку зробити надріз в шкірі, а потім розрізати іiі поступово збільшуючи отвір у краніальному напрямку. Розріз роблять обережно, щоб не пошкодити внутрішні органи. Якщо лезо ножиць трохи припідняти вгору під час розрізу можна легко уникнути пошкодження внутрішніх органів. Від клоаки до шиї роблять акуратний розріз 3 боку від серединної лінії. Особливо обережно розтинають тканини передньої частини тіла. Це пов'язано 3 тим, що в області серця та голови проходять великі кровоносні судини.

Роблячи розтин біля голови використовують ножиці меншого розміру і розрізають шкіру аж до кісток нижньої щелепи. Завдяки боковому розрізу від серединної лінії шанс розрізати непарні органи порожнини тіла, що мають медіальну локалізацію дуже малий. У середній, а особливо в каудальній 
частині тіла розташовуються жовто-білого кольору жирові тіла (рис. 3), їх кількість залежить від здоров'я змії, а також періоду розмноження. У деяких змій може бути багато жирових тіл, у інших незначна кількість. За потреби обережно видаляють жирові тіла, щоб зробити доступ до внутрішніх органів.

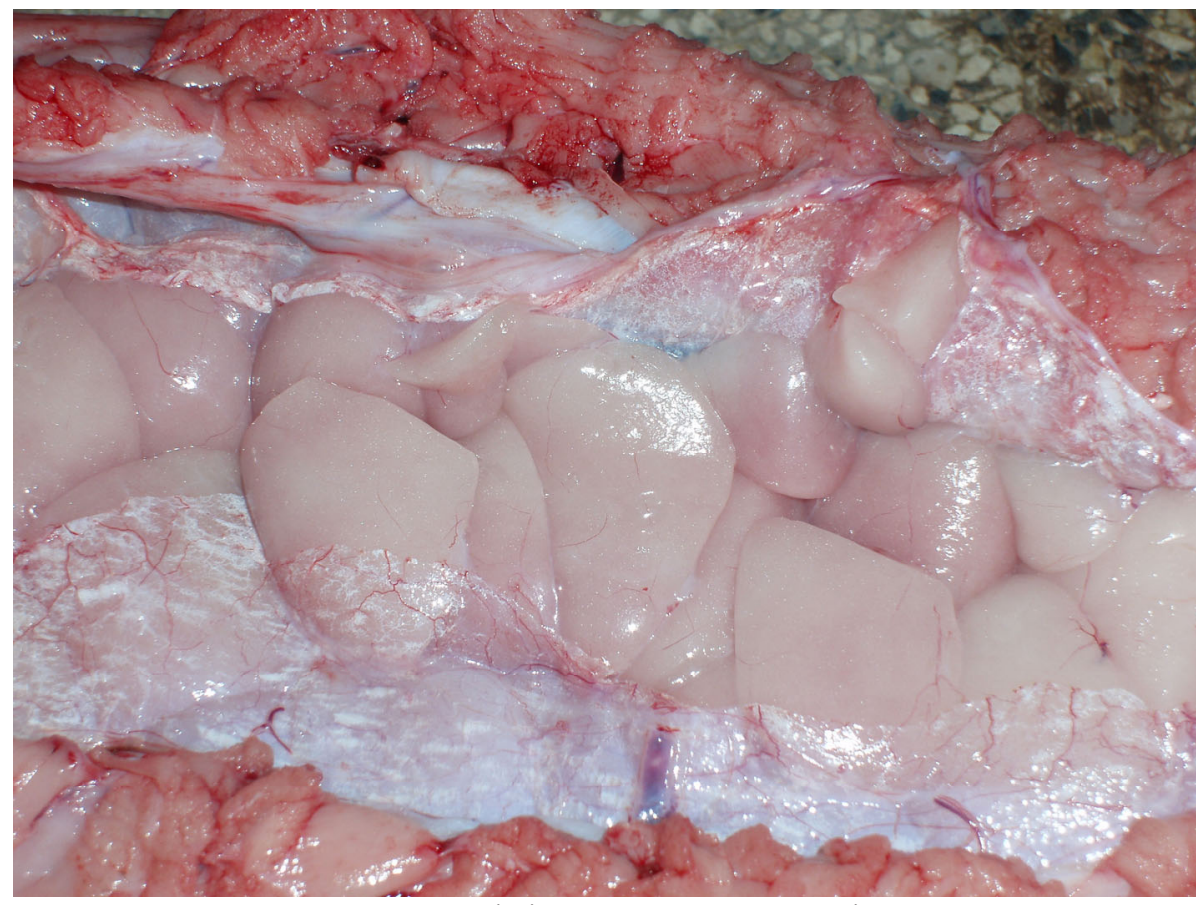

Рис. 3. Жирові тіла самки тигрового пітона

Органи дихання у змій складаються із зовнішніх носових отворів (ніздрів), носової порожнини, внутрішніх носових отворів (хоан), голосової щілини, трахеї, бронхів, легені (легень) і повітряного мішка. Діафрагми у змій немає. Хоани розміщені на даху ротової порожнини i при закритому роті сполучаються безпосередньо з голосовою щілиною. Голосова щілина лежить ззаду від язика. Під час процесу годування голосова щілина здатна зміщуватися в бік, щоб полегшити дихання під час заковтування великої здобичі.

Вентральна частина трахеї - жорсткий хрящ, а дорсальна утворена мембраною 3 губчастою тканиною, яка нерідко є додатковим органом дихання. Трахея впадає в легеню (легені) на рівні серця.

У більшості полозових (Colubridae) та деяких гадюк (Viperidae), права легеня є основною легенею, тоді як ліва регресувала до рудиментарної структури. Рудиментарна ліва легеня часто замінюється васкуляризованим повітряним мішком. Як пристосування до плавання, у водних змій права легеня простягається на всю довжину тіла. Деякі види змій мають унікальний мішкоподібний дивертикул, утворений випинанням мембрани неповних хрящових кілець трахеї, який служить для шипіння або функціонує як трахеальна легеня, яка забезпечує додатковий газообмін, коли вміст шлунка перешкоджає нормальному функціонуванню легені. У еволюційно старих видів, наприклад в удавових (Boidae), є дві легені (Kotsiumbas et al., 2011; Girling, 2013; Funk \& Bogan, 2019).

Після дослідження зовнішніх ніздрів, носових ходів, внутрішніх ніздрів та голосової щілини відпрепаровують трахею і легені (легеню). Слід пам'ятати, що легені (легеня) у змій є дуже ніжним органом, який легко пошкодити під час розтину. Права легеня $\epsilon$ досить великим органом, що простягається від серця досить каудально (локалізується у II та III квадранті тіла). У нормі внутрішня поверхня легені (легень) має комірчасту структуру (рис. 4), що значно збільшує дихальну поверхню. Альвеолярної будови легені рептилій не мають.

Найчастіше 3 патології органів дихання у змій трапляються пневмонії, що спричинені бактеріями, вірусами, патогенними мікроскопічними грибами, нематодами, артроподами, легеневими кліщами тощо.

Органи серцево-судинної системи. Серце має витягнуту форму, лежить у передній частині тіла, покрите серцевою сорочкою i $\epsilon$ рухомим, щоб забезпечити проходження великих кормів через стравохід.

Серце трикамерне, 3 двома передсердями i загальним шлуночком, функціонує як чотирикамерний орган. Наявний венозний синус, що веде до правого передсердя, від якого відділений клапаном. Змії мають дві дуги аорти, які виходять 3 шлуночка серця, а потім зливаються в черевну аорту. Легенева артерія несе венозну кров до легені (легень). Окрім ворітної венозної система печінки наявна ворітна венозна система нирок. Вентральна черевна вена лежить по серединній лінії тіла, безпосередньо під вентральною черевною мускулатурою і їі слід не пошкодити під час розтину (Kotsiumbas et al., 2011; Funk \& Bogan, 2019).

Дві зовнішні яремні вени проходять медіально від 
вентральних шийних ребер i можуть використовуватись для встановлення катетерів для внутрішньовенного введення лікарських речовин, а вентральна хвостова вена використовується для забору крові.

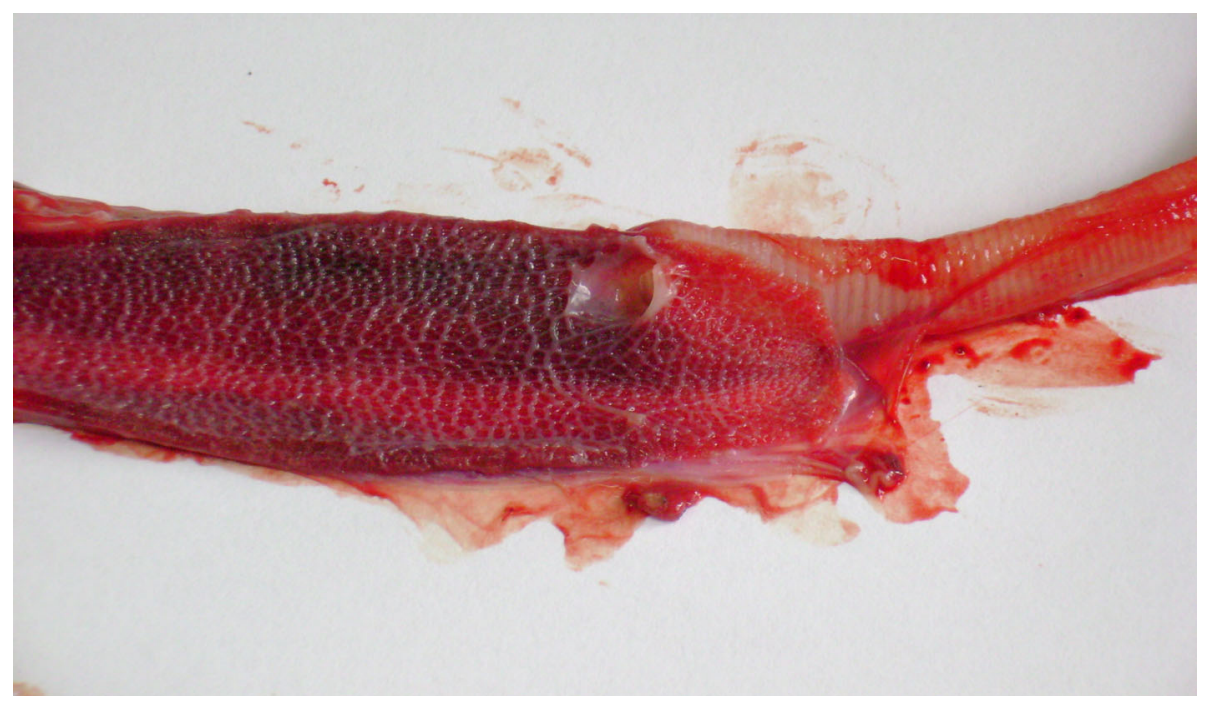

Рис. 4. Легеня тигрового пітона

Лімфатична система. У змій немає сформованих лімфатичних вузлів. Натомість, у більшості внутрішніх органів, зокрема в печінці та кишечнику та інших органах, $є$ окремі скупчення лімфоїдної тканини. Селезінка розташовується поблизу підшлункової залози та жовчного міхура. Лімфатичний синус, наприклад, проходить по довжині тіла змії прямо 3 вентро-латеральної частини епаксіальної мускулатури безпосередньо під поверхнею шкіри $з$ обох боків тіла. Також у змій наявні лімфатичні серця, що розташовуються у задній частині тіла.

3 патології серцево-судинної системи у змій найчастіше зустрічаються дистрофічні зміни в міокарді, вади серця, водянка серцевої сорочки, перикардити (у тому числі індукований відкладанням сечової кислоти та уратів), тромбоз судин тощо. Унаслідок серцево-судинної недостатності розвиваються набряки, які здебільшого локалізуються в ділянці голови.

Органи сечової системи представлені парними нирками, від яких відходять сечоводи, кожен з яких проходить через вентральну поверхню нирок. Сечоводи несуть сечу від нирок до дорсального (сечового) відділу клоаки (уродеуму). Сечового міхура у змій немає. У дорослих змій нирки метанефротичного типу (тазові нирки). У деяких анаконд (наприклад, Eunectes spp.) передня частина нирок молодих особин містить залишки мезонефроса (тулубової нирки). Парні видовжені часточкові нирки локалізуються в задній частині тіла (у четвертому квадранті) між очеревиною та м'язами стінки тіла (ретроперитоніально).

У переважної більшості видів змій права нирка розташовується краніальніше лівої (рис. 5). Симетрично розташовуються нирки лише в декількох видів (наприклад, burrowing pythons, Calabaria spp.). Нирки змій утворені часточками, що забарвлені від темно-рожевого до червоно-фіолетового кольору. Кількість ниркових часточок змінюється залежно від таксону. Чіткого макроскопічного поділу на кіркову та мозкову речовину в нирках змій не спостерігається. У змій відсутня ниркова миска та жирова капсула нирок. Каудальні ділянки нирок у самців змій формують “статеві сегменти", які збільшуються протягом сезону розмноження, оскільки їх структурні компоненти приймають участь в утворенні елементів сім'яної рідини.

Кровопостачання нирок здійснюється 3 спинної аорти, від якої відгалужується 4-5 ниркових артерій. Окрім цього, у змій, як і в інших рептилій, наявна ворітна венозна система нирок. Венозна кров із задньої частини тіла може потрапляти в нирки через аферентні ниркові вени. Наявність ворітної венозної системи нирок має важливе фізіологічне та клінічне значення. У зв'язку з наявністю ворітної венозної системи нирок парентеральне введення лікарських речовин рептиліям рекомендується проводити у передню частину тіла (Kotsiumbas et al., 2011; Chuliuk, 2021).

Як і більшість рептилій, змії урикотелічні, тобто основним продуктом азотистих відходів $€$ не сечовина, а сечова кислота. Ця сполука відносно нерозчинна, що дозволяє заощаджувати воду. Це особливо важливо для рептилій, оскільки у них немає петель Генле в нефронах, тому вони не можуть створювати гіпертонічну сечу, як ссавці. Для подальшого збереження води сеча 3 уродеумної частини клоаки може надходити назад у кінцеві відділи кишечника, де відбувається повторна реабсорбція води. 


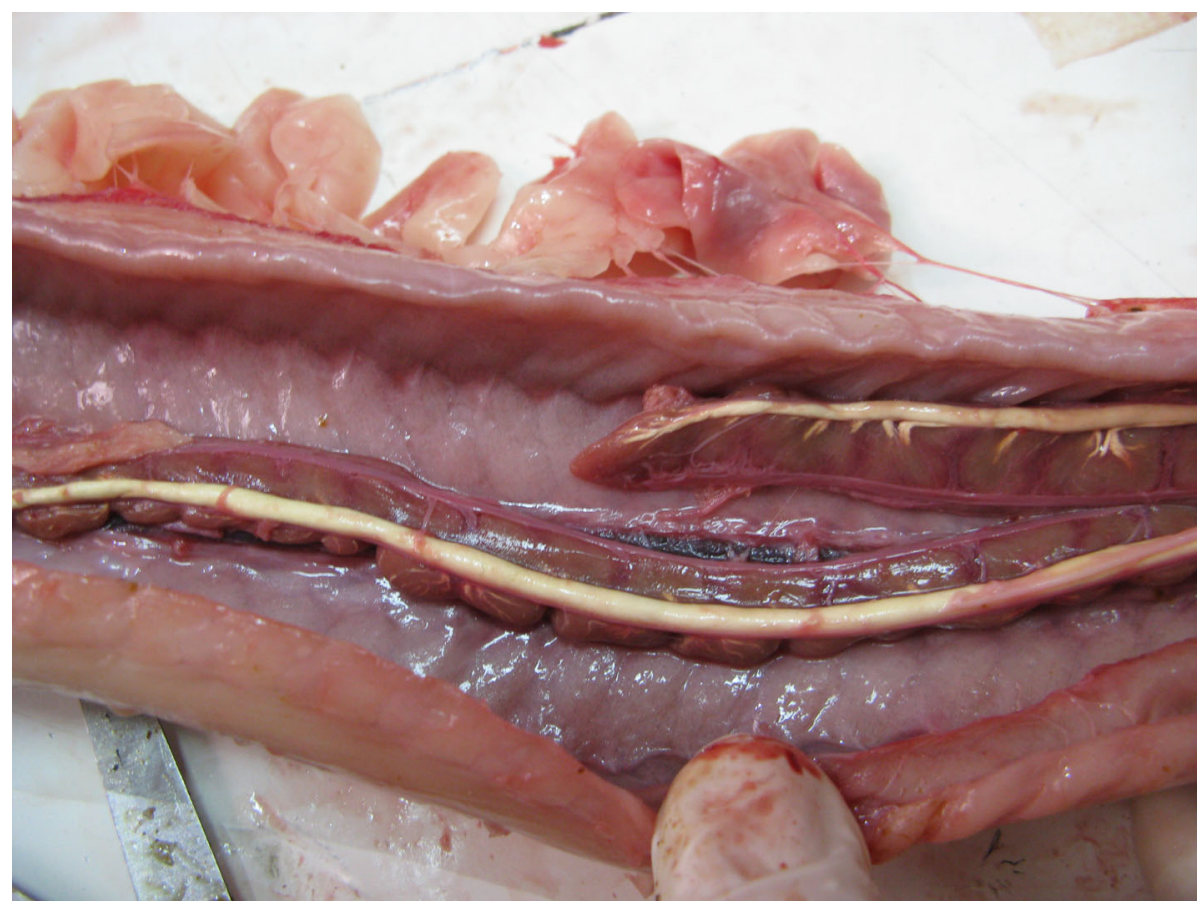

Рис. 5. Нирки та розширені, переповнені сечею сечоводи тонкохостого полоза

У нирках трапляються запальні та дистрофічні зміни, що виникають унаслідок переохолодження, порушення обміну речовин, дії мікроорганізмів, інтоксикацій. Нерідко патологія нирок або сечовивідних шляхів (наприклад, закупорка сечоводів) може спричинити розвиток вісцеральної подагри.

Органи статевої системи. Статева система самців складається 3 жовтуватих або кремових сім'яників овальної форми, розташованих в другій третині целому. Правий сім'яник розташований краніальніше лівого. Сім'яники з'єднані з сім'яною протокою, яка має вигляд тонкої, білої хвилеподібної трубки проходить від придатка сім'яника каудально уздовж кишечника, відкриваючись в клоаку до геміпенісу. Самці мають два геміпеніси, правий і лівий, які знаходяться у втягнутому стані у геміпенісному мішку задньої частини клоаки. Під час парування геміпеніси вивертаються і вводяться в клоаку самки. Геміпеніси кожного виду змій мають особливий розмір і форму, що можна використовувати для ідентифікації виду.

Репродуктивний тракт самок складається 3 довгих і тонких яєчників, розташованих попереду нирок. В період розмноження вони можуть бути заповнені яйцеклітинами. Краніальна частина яйцепроводу розширюється, утворюючи лійку. Піхва відкривається в клоаку через урогенітальний отвір або як окремий отвір у клоаку.

У самок можлива затримка відкладання яєць, що може супроводжуватись розлитим запаленням стінки яйцепроводу, інтоксикацією, яка спричиняє дистрофічні зміни у внутрішніх органах та загибель тварини. У самців ж часто відмічають випадіння геміпенісів.

Органи травлення змій. Ротова щілина у змій широка, губи та щоки відсутні. Язик локалізується в базальній піхві на ростральному кінці ротової порожнини безпосередньо перед голосовою щілиною і може висуватися через губну виїмку навіть коли рот закритий. Язик довгий, циліндричний i глибоко роздвоєний, не приймає участь в процесі заковтування здобичі. Натомість язик виконує функцію для вловлювання запахів на його вологій поверхні. Змія висовує язик 3 рота збираючи на його поверхню різноманітні речовини, після цього вводить кінці язика в ямки органу Якобсона (вомероназального органу), які локалізуються в даху ротової порожнини. Орган Якобсона пов'язаний з головним мозком і $\epsilon$ примітивним, але ефективним детектором феромонів і запахів (Kotsiumbas et al., 2011; Funk \& Bogan, 2019).

Зуби у змій розвинені добре і призначені для кусання, захоплювання, утримання здобичі i проштовхування у стравохід, але не для пережовування корму, оскільки змії заковтують здобич повністю. У зв'язку з цим у них зуби тонкі, гострі, загнуті назад, оточені складками слизової оболонки (мембранозними завісами) ротової порожнини. У отруйних видів наявні отруйні ікла, які містять канал або борозну, як правило, локалізуються у передній або задній частині верхньої щелепи. Ротова порожнина містить слинні залози, які під час проковтування корму виділяють значну кількість слини. Слинні залози виділяють водянисту слину, що зволожує здобич та слизову оболонку ротової порожнини. Отруйні залози - це модифіковані слинні залози, які продукують секрет, призначений для того, щоб знерухомити або вбити жертву, а також розпочати процес травлення (у секреті слинних змій наявні ферменти) (Kotsiumbas et al., 2011; Evans et al., 2019).

Під час огляду ротової порожнини необхідно обережно і акуратно досліджувати зуби змії та не зазнати пошкоджень. Особливо це важливо під час розтину отруйних змій, у яких досить часто трапляється гній- 
не запалення отруйних ікол та отруйної залози. За такої патології спостерігається асиметричний набряк ділянки міжщелепового простору.

Досить часто у змій реєструється виразковий стоматит. Причиною останнього поряд з недостатністю вітамінів А та С є мікроорганізми (з родів Aeromonas, Pseudomonas та ін.), що проникають в організм рептилій під час травмування слизової оболонки ротової порожнини.

Голосова щілина - це м'язова трубка на дні рота, яка може розширюватися під час ковтання здобичі. "Шипіння" змії створюється шляхом нагнітання повітря через мембрану в голосовій щілині, що змушує їі вібрувати.

Ротоглотка переходить у довгий стравохід, який $є$ може значно розтягуватись i вміщувати велику здобич. Стравохід локалізується вентрально до органів дихання і впадає у шлунок у другій половині середньої третини тіла змії.

Шлунково-кишковий тракт, як правило, досліджують в кінці розтину. Шлунок у змій однокамерний, міцний і пружний трубчастий орган, який може значно розтягуватись. Кардіальний сфінктер не виражений. Слизова шлунка містить складні залози, що виділяють як соляну кислоту, так і пепсин, а також окремі залози, що виділяють слиз.

3 шлунка корм надходить до тонкого кишечника, що не утворює виражених петель. У початковий відділ тонкого кишечника (дванадцятипалу кишку) впадають протоки підшлункової залози та жовчного міхура. Товстий кишечник відокремлений від тонкого складкою слизової оболонки. На межі між тонким та товстим кишечником в удавів та пітонів розміщена коротка сліпа кишка.

Товстий кишечник відкривається у клоаку (рис. 6), яка формує три відділи: в перший (копродеум) відкривається пряма кишка, в другий (уродеум) - протоки органів сечової та статевої систем, третій відділ - збірний. Клоакальна щілина відмежована сфінктером від прямої кишки (Kotsiumbas et al., 2011; Funk \& Bogan, 2019).

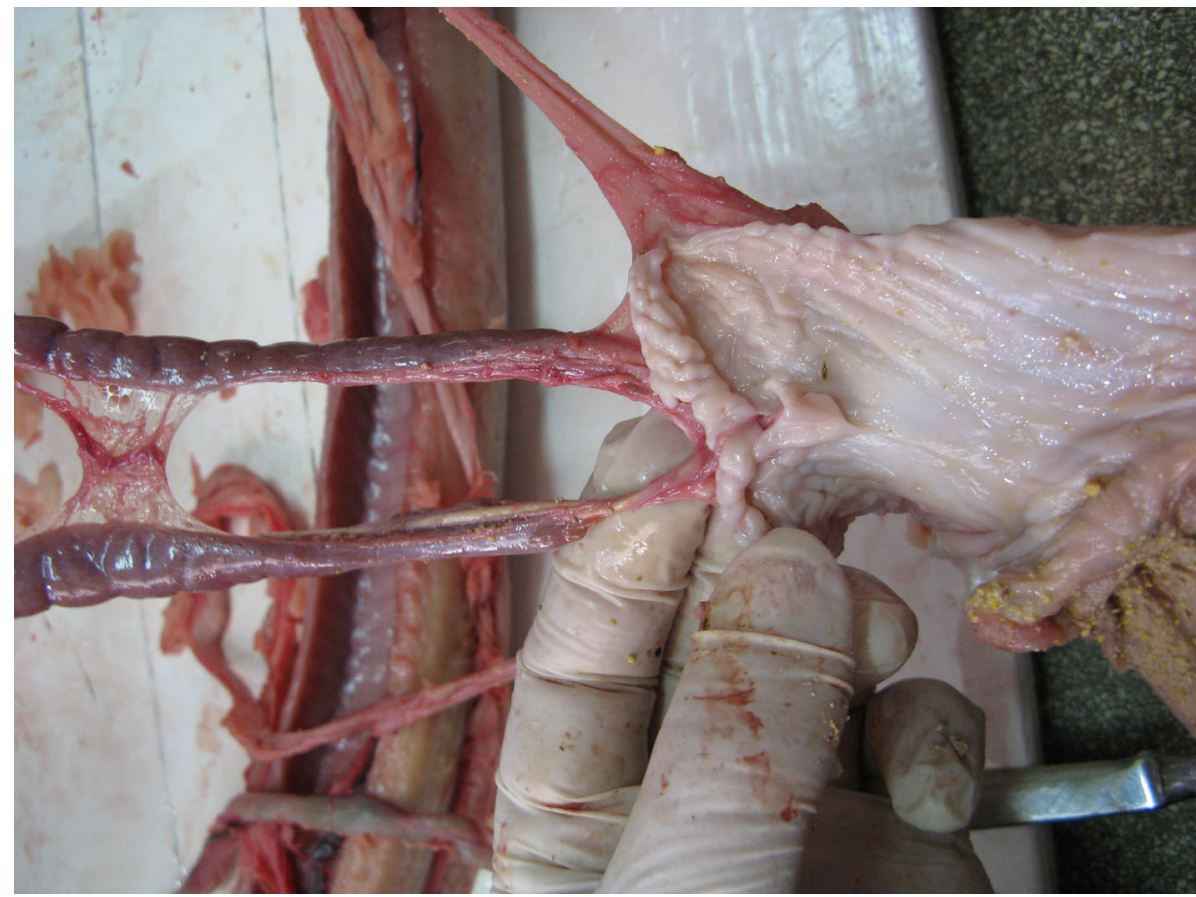

Рис. 6. Клоака тонкохвостого полоза

У змій досить часто розвиваються запальні процеси у стінці шлунка та кишечника, що спричинені розвитком бактеріальних (перш за все необхідно зважати на можливість інфікування сальмонелами), вірусних інфекцій. Унаслідок інтенсивної інвазії, поїдання сторонніх предметів, хронічних запальних процесів можливий розвиток хімо- та копростазу. Застій вмісту в шлунково-кишковому тракті також можливий після поїдання великих за розміром тварин та низької температури в тераріумі.
Печінка у змій однодольна (рис. 7), видовжена, досить об'ємна, локалізується в порожнині тіла вентрально, простягагаючись від серця до початку кишечнику.

Жовчний міхур тонкостінний, розміщений у більшості таксонів змій каудальніше печінки. Жовч надає жовчному міхуру зеленуватого кольору. Підшлункова залоза невелика, компактна, світло-білого або світложовтого кольору, розміщена поблизу шлунку та початкового відділу дванадцятипалої кишки разом з селезінкою та жовчним міхуром. 


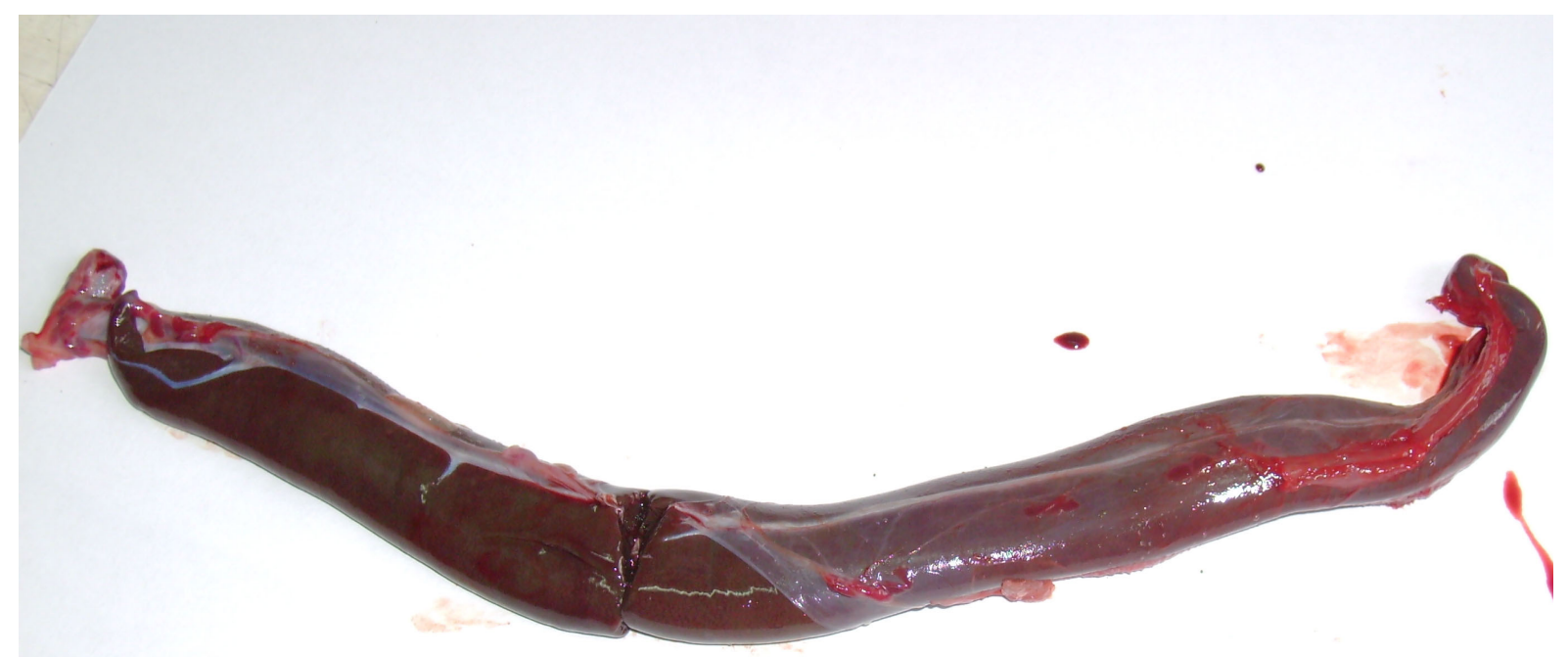

Рис. 7. Печінка тигрового пітона

Нервова система. Нервова система змій типова для інших плазунів. Мозок подовжений і складається 3 переднього мозку (кінцевий і проміжний мозок) i стовбура мозку (середній i ромбовидний мозок). Найбільш суттєвою відмінністю від ссавців і птахів $є$ наявність заднього шлуночкового валика в кінцевому мозку. Слухова частина середнього мозку та тангенціальне вестибулярне ядро добре розвинені. Зорові частки середнього мозку отримують імпульси від ока та від нюхових і слухових центрів. Мозкова речовина ромбовидного мозку виражена добре i частково охоплює великий четвертий шлуночок. У рептилій немає справжнього субарахноїдального простору, що є важливим фактором при спробі зібрати цереброспінальну рідину.

Спинний мозок проходить по всій довжині хребта до кінчика хвоста i дає початок дорсальному (сенсорному) і вентральному (руховому) корінцям у кожному хребцевому сегменті. У спинному мозку $є$ локомоторні центри. Тому відновлення після травми спинного мозку може мати кращим прогноз у рептилій, аніж у ссавців.

Унаслідок неправильного утримання (нестача ультрафіолетового випромінювання) та неправильної годівлі (недостатній вміст білків, вітамінів та мікроелементів у кормі) у змій розвивається остеодистрофія,що призводить до переломів кісток. Це може призвести до ушкодження спинного мозку та паралічів. Трапляються спонтанні травми головного і спинного мозку. Головний мозок уражається за інфікування бактеріями та нейротропними вірусами, патогенними грибами, найпростішими. Частими причинами розладів нервової системи змій $є$ недостатність тіаміну (вітаміну $\mathrm{B}_{1}$ ), отруєння фосфорорганічними сполуками.

Органи чуття. У змій відсутні рухомі повіки. Натомість рогівка захищена прозорим судинним окуляром, так званою “лінзою”, яка є ембріональним злиттям двох повік. При цьому очне яблуко невелике, a м'яз-ретрактор цибулини i мейбомієва залоза відсутні. Акомодація відбувається за допомогою зміни кривизни кришталика. Склеротичного кільця немає.

У багатьох змій також є особливі органи чуття на голові. Еволюційно старші родини змій, такі як удави, мають губні ямки - серію западин, що проходять вздовж дорсальної межі верхньої щелепи. Вони функціонують як елементарні теплові датчики. У більш еволюційно розвинених видів, таких як гадюки, органи тепловідчуття можуть фактично зосередитися на своїй жертві i складаються 3 двосторонніх, звернених вперед ямок посередині між ніздрями та очима. Вони іннервуються гілками трійчастого нерва (Kotsiumbas et al., 2011; Girling, 2013; Funk \& Bogan, 2019).

Змії не мають зовнішнього вуха, барабанної перетинки. Однак вони можуть чути звуки, що лунають у повітрі з частотою від 150 до 600 Гц, а також можуть відчувати поштовхи землі. Від внутрішнього вуха до квадратної кістки простягається одна кісточка (колумелла).

Досить частими причинами ураження очей $є$ опіки, травми, невміле надання допомоги під час линьки.

Залози внутрішньої секреції. Тимус лежить дещо попереду серця, тісно асоційований із загальною сонною артерією, яремною веною та блукаючим нервом. Тимус складається 3 правої та лівої часток, розділених ще на дві частини. Кожна доля має витягнуту форму, 3 розширеним заднім краєм та звуженим переднім. У більшості таксонів змій наявні дві пари паращитоподібних залоз, які зазвичай локалізуються між передньою та задньою частками тимуса або локалізуються у товщі цього органу. Щитоподібна залоза лежить на рівні задньої частини правої долі тимуса. Вона округлої форми, зерниста. Наднирники мають вигляд тонкого темно-жовтого тяжу, що розміщений у брижі попереду яєчників або сім'яників.

Захворювання щитоподібної залози у рептилій зустрічаються рідко, але інколи все ж реєструють розвиток зобу, що супроводжується збільшенням 
щитоподібної залози (Gyimesi et al., 2008).

\section{Висновки}

Патологоанатомічне дослідження $є$ ключовим діагностичним інструментом для встановлення причини загибелі та розуміння етіології та патогенезу захворювань. Розтин може надати цінну інформацію для оцінки ризику для інших тварин у популяції або тераріумі та допомогти власнику зрозуміти, що саме призвело до загибелі тварин. Викладені в даній статті відомості щодо особливостей нормальної морфології та техніки розтину змій допоможуть правильно проводити патоморфологічне дослідження та інтерпретувати отримані результати.

Перспективи подальших досліджень. Перспективним напрямком досліджень $є$ детальне вивчення етіології та патогенезу хвороб рептилій різного генезу. Також недостатньо вивченими $\epsilon$ особливості розвитку структурних змін у внутрішніх органах змій за інфекційної та незаразної патології плазунів. Детальний опис патоморфологічних змін за розвитку хвороб рептилій буде сприяти їх об'єктивній діагностиці, вибору ефективних методів лікування та профілактики.

Відомості про конфлікт інтересів. Автори стверджують про відсутність конфлікту інтересів щодо їх вкладу та результатів досліджень.

\section{References}

Chuliuk, W. (2021). Features of the usage of antibiotics in herpetology. Scientific Messenger of LNU of Veterinary Medicine and Biotechnologies. Series: Veterinary Sciences, 23(101), 61-66. doi: 10.32718/nvlvet10111.
Coborn, J. (1991). The Atlas of Snakes of the World. New Jersey: TFH Publications.

Evans, A. M., Choiniere, J. N., \& Alexander, G. J. (2019). Thecutting-edgemorphologyof the mole snake's dental apparatus. Peer J, 7, e6943. doi: 10.7717/peerj.6943.

Funk, R. S., \& Bogan, J. E. (2019). SnakeTaxonomy, Anatomy, and Physiology. Mader's Reptile and Amphibian Medicine and Surgery, 8, 50-62.e2. doi: 10.1016/b978-0-323-48253-0.00008-8.

Girling, S. J. (2013). Basic Reptile and Amphibian Anatomy and Physiology. Veterinary Nursing of Exotic Pets, 245-265. doi: 10.1002/9781118782941.ch17.

Gyimesi, Z. S., Garner, M. M., \& Burns, R. B. (2008). Goiter and Thyroid Disease in Captive Kirtland's Snakes, Clonophis kirtlandii. Journal of Herpetological Medicine and Surgery, 18(3), 75-80. doi: 10.5818/1529-9651.18.3-4.75

Jensen, B., Moorman A. F. M., \& Wang, T. (2014). Structure and function of the hearts of lizard and snakes. Biological revievs, 89(2), 302-336. doi: 10.1111/brv.12056.

Kotsiumbas, H. I., Dankovych, R. S., Stronskyi, Yu. S., Shchebentovska, O. M., \& Zaitsev, O. O. (2011). Khvoroby reptyli ta yi kh patomorfolohichna diahnostyka (Navchalno-metodychnyi posibnyk). Lviv (in Ukrainian).

Melidone, R., \& Gibson, C. J. (2010). Necropsy techniquesin reptiles. Part 2: Snakes. Companion Animal, 15(6), 7174. doi: 10.1111/j.2044-3862.2010.tb00500.x.

Rutland, C. S., Cigler, P., \& Kubale, V. (2019). Reptilian Skin and Its Speial Histological Structures. Veterinary Anatomy and Physiology, 1-21. doi: 10.5772/intechopen.84212.

Zakharenko, M. O., Mytiai, I. S, Kurbatova, I. M., \& Dehtiarenko, O. V (2015). Zoolohiia khordovykh: navchalnyi posibnyk. K.: vyd-vo TOV "AHRAR MEDIA HRUP” (in Ukrainian). 